\title{
ANALISIS NOVEL LASKAR PELANGI KARYA ANDREA HIRATA DENGAN PENDEKATAN UNSUR INTRINSIK DAN EKSTRINSIK
}

\author{
Feronika Hutahaean
Jurusan Pendidikan Bahasa dan Sastra Indonesia
PPs Universitas Negeri Medan
feronikahutahaean@ymail.com

\begin{abstract}
Abstrak. Penelitian ini membahas tentang analisis novel Laskar Pelangi Karya Andrea Hirata dengan pendekatan unsur intrinsik dan ekstrinsik. Salah satu karya sastra yang bercerita banyak tentang kehidupan masyarakat adalah novel. Salah satu analisis yang dapat dilakukan terhadap sebuah karya sastra dapat yakni dengan pendekatan unsur intrinsik dan ekstrinsik. Adapun unsur-unsur intrinsik pada sebuah novel adalah Tema, Penokohan, Alur, Latar, Sudut Pandang, Amanat, Gaya Bahasa sedangkan unsur ekstrinsik terdiri dari empat bagian yaitu Biografi Pengarang, Psikologi Pengarang, Lingkungan Masyarakat Pengarang, Pemikiran Pengarang.
\end{abstract}

Kata Kunci : Analisis, Pendekatan Unsur Intrinsik dan Ekstrinsik, Novel Laskar Pelangi

\section{PENDAHULUAN}

Proses penciptaan suatu

karya sastra, pengarang tidak hanya mengekspresikan apa yang ada pada jiwa mereka ke dalam suatu karya sastra, tetapi diperlukan kemampuan pendidikan yang mapan dan kejelian dalam menganalisis serta memasukkan ilmu lainnya, seperti psikologi, filsafat, antropologi, sosiologi, dan lain-lain. Dengan pendidikan yang mapan dan kejelian menganalisis serta memasukkan pengetahuan lainnya ke dalam suatu hasil karya sastra, karya sastra tersebut terasa bermanfaat di samping mempunyai unsur kenikmatan.

Dasar penggunana bahasa dalam karya sastra bukan sekedar kata itu mengusik dan meninggalkan kesan kepada pembaca. Nilai konotasi yang lebih luas dari pengertian denotasi amat penting. Setiap karya yang dipilih boleh diasosiasikan kepada berbagai daerah. Oleh sebab itulah, dalam karya sastra tidak ada pengertian 
yang sama bila ditinjau dari sudut kesan sensitivitias, dari sudut bunyi, lambang. Setiap pilihan kata mempunyai pengertian tersendiri, misalnya kata cantik, molek, bagus, baik, anggun, indah, dari sudut denotasi mungkin artinya sama, tetapi kesan kata-kata ini berbeda.

Sastra menjelaskan kepada kita tentang konsep sastra sebagai salah satu disiplin ilmu humaniora yang akan mengantarkan kita ke arah pemahaman dan penikmatan fenomena yang terkandung di dalamnya. Sastra adalah suatu bentuk dan hasil pekerjaan seni kreatif yang objeknya manusia dan kehidupannya dengan menggunakan bahasa sebagai mediumnya (Atar Semi dalam Sutresna: 2006). Berangkat dari hal tersebut, karya sastra tidak terlepas dari nilai-nilai yang dikandungnya

\section{KAJIAN TEORI}

\section{Pengertian Novel}

Novel adalah karangan prosa yang panjang mengandung rangkaian cerita kehidupan seseorang dengan orang di sekelilingnya dengan menonjolkan watak dan sifat setiap pelaku (KBBI).

Editorial Padi $(2013 ; 45)$ novel adalah sebuah karya fiksi prosa yang tertulis dan naratif. Biasanya dalam bentuk cerita. Novel lebih panjang (setidaknya 40.000 kata) dan lebih kompleks dari cerpen, dan tidak dibatasi keterbatasan struktural dan metrikal sandiwara atau sajak. Umumnya, sebuah novel bercerita tentang tokoh-tokoh dan kelakukan mereka dalam kehidupan sehari-hari, dengan menitikberatkan pada sisi-sisi yang aneh dari naratif tersebut.

Buku Padi Editor (2013: 3) jenis wujud sastra dilihat dari bentuknya, sastra terdiri atas 4 bentuk, yaitu :

a. Prosa, bentuk sastra yang diuraikan menggunakan bahasa bebas dan panjang tidak terikat oleh aturanaturan seperti dalam puisi.

b. Puisi, bentuk sastra yang diuraikan dengan menggunakan bahasa yang singkat dan padat serta indah. Untuk puisi lama, selalu terikat oleh kaidah atau aturan tertentu, yaitu :

1. Jumlah baris tiap-tiap baitnya 
2. Jumlah suku kata atau kata dalam tiap-tiap kalimat atau barisnya

3. Irama

4. Persamaan bunyi kata

c. Prosa liris, bentuk sastra yang disajikan seperti bentuk puisi namun menggunakan bahasa yang bebas terurai seperti pada prosa

d. Drama, yaitu bentuk sastra yang dilukiskan dengan menggunakan bahasa yang bebas dan panjang, serta disajikan menggunakan dialog atau monolog. Drama ada dua pengertian, yaitu drama dalam bentuk naskah dan drama yang dipentaskan.

Pendekatan Intrinsik dan Ekstrinsik

Mursini $(2010 ; 107)$ unsur
intrinsik prosa terbagi atas tujuh
bagian, yaitu:

1. Tema

Tema adalah gagasan yang mengikat cerita (Lukens, 2003;129), mengikat berbagai unsur intrinsik yang membangun cerita sehingga tampil sebagai sebuah kesatupaduan yang harmonis.

2. Penokohan

Penggambaran tokoh-tokoh cerita yang menjadi fokus perhatian baik karena pelukisan fisik maupun karakter yang disandangnya.

3. Alur

Alur adalah hubungan dengan berbagai hal seperti peristiwa, konflik yang terjadi dan akhirnya mencapai klimaks, serta bagaimana kisah itu diselesaikan.

4. Latar

Latar adalah merujuk pada tempat yaitu dimana lokasi cerita terjadi, waktu kapan cerita itu terjadi, dan lingkungan sosial budaya, keadaan kehidupan bermasyarakat, tempat tokoh dan peristiwa terjadi.

5. Sudut Pandang

Sudut pandang adalah cara atau pandangan yang digunakan pengarang sebagai sarana menampilkan tokoh, tindakan, latar, dan sebagai 
peristiwa yang membentuk cerita dalam sebuah teks fiksi kepada pembaca

(Nurgiyantoro, 2005;248)

6. Amanat

Amanat adalah pesan yang ingin disampaikan kepada pembaca yang berurusan dengan moral.

7. Gaya Bahasa

Gaya bahasa adalah usaha yang dilakukan untuk membangun jalinan cerita dengan pemilihan diksi, ungkapan, majas (kiasan) yang menimbulkan kesan estetik dalam karya sastra.

Rene Wellek (1977) unsur ekstrinsik prosa terbagi atas empat bagian yaitu :

1. Biografi Pengarang

Unsur ini memaparkan sejauh mana pengarang memberi masukan tentang penciptaan karya sastra. Tetapi, biografi dapat juga dinikmati karena mempelajari hidup pengarang yang jenius, menelusuri perkembangan moral, mental, dan intelektual. Biografi dapat juga dianggap sebagai studi sistematis tentang psikologi pengarang dan proses kreatif.

2. Psikologi Pengarang

Psikologi membantu mengentalkan kepekaan mereka pada kenyataan, mempertajam kemampuan pengamatan, dan memberi kesempatan untuk menjajaki pola-pola yang belum terjamah sebelumnya. Dalam karya sastra kebenaran psikologi baru mempunyai nilai artistik jika ia menambah koherensi dan kompleksitas karya. Dengan kata lain, jika kebenaran psikologis itu sendiri merupakan suatu karya seni.

3. Lingkungan Masyarakat Pengarang

Setiap pengarang adalah warga masyarakat, ia dapat dipelajari sebagai makhluk sosial. Biografi pengarang adalah sumber utama tetapi studi ini juga dapat meluas kelingkungan atau tempat pengarang tinggal dan berasal. Kita dapat 
mengumpulkan informasi tentang latar belakang sosial, latar belakang keluarga, dan posisi ekonomi pengarang.

4. Pemikiran Pengarang Karya sastra dapat dianggap sebagai dokumen sejarah pemikiran dan filsafat, karena sejarah sastra sejajar dan mencerminkan sejarah pemikiran. Secara langsung atau melalui alusi-alusi dalam karyanya, kadangkadang pengarang menyatakan bahwa ia menganut aliran filsafat tertentu, mempunyai hubungan dengan pahampaham yang dominan pada zamannya, atau paling tidak mengetahui garis besar ajaran paham-paham tersebut.

\section{HASIL PENELITIAN}

\section{Analisis Unsur Intrinsik Pada Novel Laskar Pelangi Karya Andrea Hirata}

TEMA : Perjuangan

Awal dari kisah laskar pelangi inipun dimulai dengan perjuangan untuk mendapatkan sepuluh murid baru oleh dua orang guru di SD Muhammadiyah untuk mempertahankan kelangsungan eksistensi SD Muhammadiyah di Belitong. Kemudian penggambaran keadaan SD Muhammadiyah yang memperhatinkan.

Bab 4, dilukiskan penggambaran perjuangan seorang guru dalam membangkitkan semangat pendidikan di SD Muhammadiyah Belitong. Pengarang juga menekankan pada pengkotakkotakan di dalam meraih sesuatu yang lebih baik, baik itu pendidikan maupun pola hidup di Belitong dikarenakan adanya sebuah Perusahan Timah. Untuk pendidikan Hirata menggambarkan perbedaan yang sangat menonjol dalam sarana maupun sarana belajar untuk meraih cita-cita, antara sekolah PN dengan SD Muhammadiyah. Akan tetapi hal yang menakjubkan di dalam novel ini setiap bab menunjukkan peristiwa yang mengejutkan. contohnya adalah pengarang menampilkan beberapa tokoh yang mempunyai semangat belajar yang tinggi dengan disertai bakat mereka yang sangat luar biasa. Salah satunya adalah Lintang. 
Bab 10 hal yang menakjubkan itu dimulai, membuat hati setiap orang akan bergetar melihat, merasakan perjuangan seorang anak nelayan yang benar-benar ingin sekolah dengan jalan menempuh jarak sekolah yang sangat jauh dengan berbagai rintangan yang ia temui di perjalanan. semangat belajar lintang yang begitu kuat, semua itu karena ia rajin membaca, belajar, menganalisis, serta berusaha mencari solusi kehidupannya. Selanjutnya

Bab ke 32 digambarkan perjuangan ikal di dalam meraih citacita dengan berusaha yang ekstra. Inilah hasil pendidikan yang di ajarkan kepada laskar pelangi untuk member sebanyak-banyaknya bukan menerima sebanyak-banyaknya.

Jadi dapat disimpulkan bahwa Tema Novel Laskar Pelangi, semangat perjuangan yang disertai dengan keikhlasan sebelas orang anggota laskar pelangi dalam menempuh pendidikan. Mereka dengan segala kekurangan dan keterbatasan yang ada namun mereka pantang menyerah dalam menuntut ilmu.

\section{Amanat}

Amanat dari novel Laskar pelangi yang disajikan pengarang ini menggunakan cara penyampaian amanat secara eksplinsit dan implinsit, tetapi dalam hal ini yang lebih dominan adalah cara penyampaian secara eksplisit. Nasib tokoh utama di dalam novel ini berakhir bahagia karena dapat melanjutkan studinya ke luar negeri. Semua itu karena perjuangan tokoh utama.

Adapun amanat yang dapat kumpulkan dalam novel laskar pelangi karya Andrea Hirata adalah

1. Untuk memberikan inspirasi dan semangat kepada para guru dan pelajar yang berada di dalam pendidikan, karena pendidikan sangatlah penting bagi kita semua walaupun dalam berbagai tantangan yang melanda pada diri kita(pelajar), (bab 1 hal 6-7)

2. Kemiskinan dan kekurangan fasilitas pendidikan bukanlah suatu hal yang menghambat terpuruknya seseorang untuk menempuh ilmu dan mempunyai pandangan buruk tentang keadaan tentang serba 
sederhana. Semangat dan pandangan hidup kedepan akan membuat seseorang mampu melampaui masa sulit dalam menempuh pendidikan. (bab 1 , $4,10)$

3. Sebagai penerus generasi penerus bangsa setiap individu harus mempunyai dedikasi tinggi terhadap pendidikan. Khususnya seorang guru, di dalam proses mendidik sebaiknya dapat mengajarkan tentang nilai-nilai dasar kehidupan seperti akhlak, kejujuran, dasar-dasar moral dan agama, selain itu, dalam mengajar sebaiknya tanpa pamrih dan mengajar dengan hati yang ikhlas(guru) (bab 11 dan Bab 4 hal 32)

4. Dalam menggapai cita-cita, hendaknya tidak mudah menyerah atau putus asa, walau cita-cita itu tidak mudah diraih dan diwujudkan sesuai keinginan. Berusahalah sekuat tenaga untuk meraih semua mimpi dan cita-cita walau dalam himpitan ekonomi dan keterbatasan. (bab 32 hal 472 : $2,474: 2,476: 1)$
Amanat yang disampaikan oleh pengarang lebih dominan menggunaka tekhik implicit dikarenakan kolersinya dengan tema yang dapat ditebak. Tekhnik yang dipilih ini pun dinilai tepat oleh pembaca secara umum karena mereka mampu dengan mudah pesan apa yang ingin disampaikan oleh pengarang kepada pembaca.

\section{PENOKOHAN}

Penokohan ialah tokoh-tokoh dan karakteristik yang diperankan oleh para tokoh, pada kajian penokohan yang akan dijelaskan mengenai para tokoh yang paling dominan muncul atau berperan pada tiap babnya. Diawali oleh tokoh utama dan para tokoh lainnya.

1. Ikal ( $a k u)$ : Seorang tokoh utama pada Novel ini, Ikal adalah anak pegawai PN Timah rendahan. Ikal adalah seorang siswa Muhamadiyah yang punya tekad yang kuat untuk meraih cita-cita agar tidak menjadi kuli panggul dan bias merubah hidup keluarganya. Ikal adalah tokoh yang sangat setia kawan, ramah, sabar, dan juga cukup pintar, Ikal juga 
sangat berbakti kepada kedua orang tua dan sekolah. Ikal tidak pernah merasa putus asa dengan apa yang ia perjuangkan. Ikal yang paling tidak menginginkan menjadi tukang pos, namun setelah dewasa Ikal bekerja sebgai pegawai kantor pos, sebelum Ikal mendapatkan Beasiswa.

2. Lintang: Anak pesisir pantai dari seorang Nelayan, Linatang sangat ingin punya cita-cita yang tinggi karena diantara 6 bersaudara hanya ia yang berkeinginan untuk bersekolah. Lintang ialah seorang anak yang sangat berjuang demi pendidikannya. Lintang juga sangat berbakti terhadap orang tua nya. Lintang sosok anak yang sangat bertanggung jawab, namun tidak pada tubuhnya, karena Lintang sangat tidak terawat tubuhnya. Badan Lintang berbau hangus , rambut keriting. Namun soal otak, Lintang punya otak yang sangat Brilian, pintar dan sangat jenius, namun ia tidak pernah sombong atas kepintaran yang ia miliki,
Lintang juga sangat setia kawan, selain itu ia juga hobi membaca (100: 2). Lintang terpaksa berhenti sekolah, karena Ayahnya meninggal dunia, Lintang harus menggantikan ayahnya untuk menopang hidup 14 Jiwa di rumahnya ( hal 88, 93, 113, 114) .

3. Mahar: Seorang Siswa Muhamadiyah yang sangat mahir dalam bidang seni (hal 143), hingga Mahar sangat pintar bernyanyi dengan suaranya yang merdu ( hal 138). Dan juga di dukung dengan wajahnya yang sangat rupawan (13:2). Namun Mahar sangat perduli dengan temantemannya (hal 148). Mahar juga punya tekad yang kuat terhadap apa yang ia inginkan. Walau akhirnya Ia hanya menjadi pembuat dokumentasi permainan anak tradisional.

4. Trapani: Seorang siswa Muhamadiyah yang sangat rapi dan bersih, perfeksionis, santun (hal 74: 1) dan sangat berbakti kepada Ibunya (hal 75: 2), Trapani juga tampan seperti 
Mahar,. Namun Trapani sangat

tidak beruntung, karena ketergantungannya Trapani harus menghuni Rumah Sakit Jiwa bersama ibunya.

5. Kucai : Ketua kelas yang selalu mengeluh minta digantikan jabatannya. Kucai sosok anak yang sangat sok gengsi berwajah manis manja namun dia juga Lemot dalam pelajaran. Kucai pada saat kecil kekurangan gizi, sehingga dia mengalami rabun jauh. Kucai sangat pintar hanya dalam bidang politik dengan mulut besarnya, dia juga mempunyai sikap yang Optimis, Populis, Opurtunis (hal 69). Hingga dewasa ia menjadi seorang politisi dari salah satu fraksi DPRD di Belitong.

6. Borek: anak yang bertubuh paling besar hingga di juluki "Samson" ini sangat nakal, susah diatur, dan sangat ingin menjadi cowok Macho ( hal 78), namun ia juga sangat konsisten terhadap apa yang ingin ia capai (hal 67), namun sayangnya setelah dewasa ia hanya menjadi kuli toko yang dimiliki oleh A kiong dan Sahara.

7. Harun: Seorang anak yang keterbelakangan mental , berkaki ' $\mathrm{X}$ ', namun ia selalu rapi di banding temantemannya. Rambutnya seperti Chairil Anwar. Sosok anak yang sangat ceria, mudah senyum, santun, pendiam, teman yang baik (hal 76). Namun selalu mendapatkan rapot khusus. Selalu bertannya kapan libur lebaran.

8. Syahdan: Anak seorang nelayan yang memiliki tubuh kecil, namun selalu ceria, tukang dempul perahu, pekerja keras, tidak putus asa (Hal 67).

9. Sahara: Seorang gadis muslimah yang berjilbab, bertubuh ramping, anak dari atasan kepala parit PN Timah. Gadis yang keras kepala tapi tegas dalam bersikap, perhatian,skeptic, jujur ,tetapi ketus terutama pada Akiong (hal $14: 1$ ).

10. A kiong: Seorang anak konghucu yang hidup dari sebidang kebun sawi, bermuka lebar , rambut serupa landak, 
mata tertarik keatas, gigi tongos ( hal 68),namun baik dan sangat polos kecuali kepada sahara (85: 2). Menyimpan perasaan pada sahara. Masuk islam, lalu berubah nama menjadi muhammadjundullah gufron nur zaman.

11. N.A. Muslimah : Seorang guru yang pandai, karismatik, pantang menyerah, ramah, baik, mengajar seluruh pelajaran, pekerja keras, bertanggung jawab,dan selain mengajar dia juga menjahit ( hal 30: 1).

12. K.A. Harfan Efendi: K.A. Harfan Efendi Noor ini adalah seorang kepala sekolah yang berkumis tebal, rambut yang sudah beruban, berjenggot, pintar, pekerja keras, baik, dan bijaksana. ( hal 20: 2, 21, 24, 25:1)

13. Flo : Seorang anak gedong yang kaya raya, percaya ilmu gaib, sangat tomboy, baik, tidak mudah dipengaruhi atau berubah pendiriannya, keras kepala (hal 46: 1 baris 2). Yang akhirnya berubah menjadi baik hingga memakai jilbab.
14. Bodenga : Pawang buaya yang selama hidup selalu dikelilingi buaya, baik, penyayang hewan, dingin, tidak ramah, wajahnya carut marut dan usianya kirakira empat puluhan. ( hal: 91)

15. Ibu Frischa : sebagai kepala SD PN. Ia adalah seorang wanita keras yang terpelajar, progresif, serta tinggi hati. (Hal 60:2)

16. Eryn Resvalda $N$ : seorang mahasiswa yang berjuang untuk menulis tugas akhirnya, cerdas, agamis, cantik dan baik hati (hal $443: 1$ )

17. Prof Yan: Seorang dokter jiwa yang sangat berpengalaman yang baik hati ( hal 449)

Menggambarkan karakter tokoh tersebut, pengarang lebih dominan menggunakan takhnik analitik. Hamper seluruh tokoh digabarkan oleh pengarang dengan menggunakan teknik ini. Efek yang ditimbulkan dari penggunaan tekhnik ini secara umum memudahkan pembaca untuk memahami karakter setiap tokoh. Setiap tokoh mampu digambarkan secara unik dan kreatif oleh pengarang. Karena pemilihan 
anggota fisik tokoh yang dipilih pengarang menyebabkan pembaca tertawa sekaligus sedih melihat keterbatasan fisik mereka. Andrea mampu memberikan deskripsi dengan detail yang kuat.

\section{SUDUT PANDANG}

Secara umum tokoh ikal yang berperan penting di dalam pengungkapan peristiwa-peristiwa yang terjadi, selain itu pengarang menggunakan tokoh lain seperti syahdan dalam menuturkan ceritannya dengan peran yang lain tanpa mengubah maksud dan efek ceritannya. Pengarang menggunakan sudut pandang ini untuk memperindah karyanya dan memebrikan ciri khas karakteristik. Pengarang mencerminkan sifatnya dalam penuturan ceritanya melalui tokoh ikal dan syahdan. Adapun gaya pengarang yaitu selalu ingin maju untuk mencapai kesuksesan seperti sekarang ini. Pengarang juga menggunakan bahasa istilah sains yang dipahaminya dan dituangkan dalam karya-karyanya.

Didalam laskar pelangi pengarang berperan langsung sebagai orang pertama, sebagai tokoh cerita.
Hal itu dapat kita lihat bahwa pengaranga menggungakan istilah aku dalam ceritanya. Jadi, dalam hal ini, pengarang sendirilah yang menjadi tokoh utamanya. Penggunaan istilah aku di dalam cerita menandakan bahwa pengarang sedang menceritakan sebagian pengalamannya yang dapat ia tonjolkan bahan sebuah Novel.

Penggunaan sudut pandang ternyata pengarang tidak konsekuen menggunakan sudut pandangnnya, itu dapat kita lihat di dalam bab 34 dalam Laskar Pelangi. Efek penggunaan sudut pandang seperti itu menimbulkan dua presepsi, pertama pembaca banyak terjebak ketika membaca Laskar Pelangi. Terjebak karena bingung tiba-tiba pengarang berkata "setelah tamat SMA, Aku, Ikal, Trapani, dan Kucai memutuskan untuk merantau ke jawa" (bab 34: 492).
ALUR
Alur laskar pelangi bisa dikatakan tersusun sangat rapi dan maju kedepan, dalam arti peristiwa- peristiwa disusun secara kronologis berdasarkan waktu kejadiannya, akan tetapi tidak jarang ada terjadi 
pengulangan kembali (Flashback) untuk memperjelas permasalahan pokoknya. Tiap tiap peristiwa mempunyai makna dalam fungsinya untuk menjelaskan konflik-konflik antara pengarang dengan lingkungannya sehingga terwujudnya tema cerita yang mendasarninya. Jadi dapat dikatakan adanya keterjalinan antara penokohan membentuk peristiwa-peristiwa yang akhirnya membentuk sebauah tema.

Secara ringkas alur Laskar Pelangi dapat di kemukakan sebagai berikut. Cerita dibuka dengan Pengenalan Situasi, kecemasan seorang guru dan perjuangan seorang anak untuk menggapai cita-cita, setelah itu di dalam proses perjuangan itu terdapat keterbatasan fisik, baik tertuju kepada sekolah maupun kepada fisik tokoh, serta keadaan lingkungannya. Setelah itu, mulailah Pengungkapan Peristiwa awal yang menimbulkan banyak pertetentangan maupun kesukarankesukaran bagi para tokohnya.. Tokoh lintang yang menemui kesukaran seperti menepuh sekolah yang jaraknya sangat jauh, serta harus bertemu dengan buaya pada hampir setiap harinya.
Penemuan siswa berbakat seperti Lintang dan Mahar. setelah itu mulai Menuju Pada Adanya Konflik, ini hanya sebagai contoh kecil dari keseluruhan konflik yang ditimbulkan. flo yang ingin menjadi seperti laki-laki hingga terbentuknya perkumpulan mistis yang terdapat pertentangan manusia dengan tuhannya oleh flo, mahar, dan tokoh lainnya. Akan tetapi, yang jelas konflik bermula ketika antara pengarang mampu melihat realitas yang terjadi di belitong, pengarang yang diperankan oleh tokoh aku dengan lingkungannya, perbedaan yang sangat di dalam sarana dan prasarana pendidikan antara SD PN dengan SD Muhammadiyah perbedaan itu tidak menjadikan semangat belajar Siswa SD Muhammadiyah menjadi lemah. Terbukti berbagai perestasi yang dihasilkan oleh Lintang dan Mahar pada acara karnaval 17 agustus dan lomba cerdas cermat, inilah hal yang paling menegangkan sekalius membanggakan para orang tua, guru, dan SD Muhammadiyah ketika lintang dapat menjawab pertanyaan pertanyaan dalam hitungan detik, 
ketika lintang mampu menjelaskan tentang teori sains kepada para juri.

Konflik Ini Memuncak Peristiwa yang tidak terduga terjadi tokoh lintang akhirnya harus berhenti sekolah dikarenakan bapaknya meninggal dan Trapani yang sangat santun terhadap orang tua dan temannya akhirnya gila yang digambarkan secara jelas dan sederhana. Flo, mahar dan anggotanya yang lain ketika pergi untuk menemui seorang dukun terkenal ternyata harus rela dikecewakan oleh berbagai ilmu mistis yang mereka pikirkan, ternyata pesan dari dukun itu adalah kalau ingin pintar ya belajar.

Akhir Cerita, pada bagian ini berisi penjelasaan tentang nasibnasib yang dialami para tokoh setelah mengalami peristiwa puncak itu, konflik atau pertentangan yang terjadi telah mengantarkan para tokoh mengalami perubahan nasib . berawal dari pertentangan itulah, timbul kesadaran baru, ikal yang berhasil melanjutkan cita-citanya sekolah ke luar negeri, tapi menyedihkan untuk lintang yang jenius ternyata sekarang menjadi pekerja rodi. mahar dan flo yang insyaf, flo menempuh perguruan tinggi di FKIP Universitas Sriwijaya. Setelah lulus ia menjadi guru Tk di tanjong pandan (hal 473-474) dan mahar sibuk mengajar dan mengorganisasikan berbagai kegiatan budaya (hal 477), A kiong masuk islam dan menjadi seorang muslim yang taat (hal 464-465). Sahara dan Samson pun akhirnya menikah (hal 467). Syahdan yang menemukan keahliannya di bidang computer. Ia mendapatkan beasiswa ke Kyoto University jepang dan akhirnya menduduki posisi sebagai Information technology manager di sebuah perusahaan multinasional yang terkemuka yang berpusat di tanggerang (hal 478-479). Kucai yang menjadi seorang politisi dengan gelar yang paling tinggi di bandingkan dengan tokoh yang lain.

\section{SETTING}

Sebuah novel tentu terdapat latar yang sangat kompleks. Di dalam Laskar Pelangi memerlukan tempat yang lebih beragam dan waktu yang lama. Pulau Belitong adalah salah satu setting secara umum yang melatar belakangi peristiwa yang terjadi tepatnya di 
desa terpencil (Bab 7, 49-50) . Pengarang memilih latar tersebut didasari kepentingan atas tema, alur, dan penokohan. Latar atau setting pada karya sasta Laskar Pelangi ini termasuk realitas objektif yaitu benar - benar dialami oleh pengarang dan pembaca mengetahui latar tempatnya. Di samping itu dengan mengetahui latar, pembaca mempunyai persepsi tentang peristiwa, walaupun pada akhirnya persepsi itu akan dibuyarkan oleh tindakan tokoh.

Setting yang menggambarkan Suasana yang sangat menyedihkan adalah SD Muhammadiyah. Beberapa setting bersifat fisikal seperti Pohon filicium, rawa dan sungai, toko kelontang, pulau lanum dan pantai pangkalan punai. Setting itu juga mempunyai hubungan dengan perwatakan para pelaku, jarak rumah lintang dengan sekolah telah mampu menciptakan karakter lintang yang tegar, berani, pantang menyerah di dalam berjuang menempuh pendidikan. Ikal yang hidup di tengah lingkungan yang keterbatasaan mampu menjadikannya mempunyai semangat untuk berusaha memperoleh kehidupan yang lebih baik. Itu semua dikarenakan kondisi belitong yang sangat erat dengan perbedaan status antara PN timah dengan lingkungan sekitarnya.

Hubungan setting dengan tema pun terlihat, Sekolah yang memperhatinkan tidak merubah semangat mengajar dan belajar para guru dan siswa. Alam yang luas, indah, dan panorama pulau belitong di jadikan sebagai sumber inspirasi di dalam membentuk kreatifitas mereka. Jarak yang jauh di dalam menempuh cita-cita semakin membentuk pribadi yang tegar. Sampai-sampai seorang siswa SD PN ingin bersekolah di sekolah yang sangat memperhatinkan. Semua karena keterbatasan terkadang menjadi penyebab bagi seseorang untuk produktif dan kenyamanan terkadang tidak mampu memaksa seseorang untuk produktif. Setting yang ada di dalam laskar pelangi ini seolah-olah ingin menyampaikan pesan kepada kita, keadaan yang begitu memperhatinkan seperti itu saja, guru dan siswa sama-sama ingin mengajar dan belajar.

\section{GAYA BAHASA}


Gaya bahasa berfungsi untuk menciptakan suatu nada atau suasana persuasif. Bahasa digunakan pengarang untuk menandai atau mengetahui karakter seorang tokoh. Bahasa dapat menimbulkan suasana yang tepat bagi adegan yang seram,adegan cinta,dan keputusan,yang menjadi pusat perhatian dalam karya sastra adalah masalah penggunaan bahasa dalam mengungkapkan ide atau tema yang di ajukan didalam karya sastra, apakah bahasa yang digunakan cocok dengan persoalan yang tengah dibicarakan.

Gaya bahasa yang digunakan dalam Laskar Pelangi mampu menimbulkan suasana yang beragam. Menimbulkan suasana yang simpatik, objektif, harapan dan citacita. Kosa kata dari etnis tertentu terkadang menimbulkan kekaguman pada setiap kata-kata yang menggunakan majas metafora, menjelaskan respon tokoh pada setiap peristiwa tentang makna laskar pelangi, tapi disisi lain juga terkadang menimbulkan kebuntuhan untuk memaknai kosa kata yang teramat tinggi untuk di baca secara umum.
Gaya yang digunakan sangat menarik karena penggunaan metafora dan deskripsi hamper dapat ditemukan pada setiap bab. Pemilihan gaya bahasa, kata, dan penataan kalimat sehubungan dengan makna dan suasana menimbulkan efek yang beragam. Pengarang lebih memilih penggunaan gaya bahasa itu karena, pengarang ingin berusaha meyakinkan, berusaha memahami kondisi yang terjadi. Gaya bahasa itu telah berhasil menggambarkan watak, setting, serta alur dengan begitu kuat. Contoh pelukisan suasana di dalam laskar pelangi bisa dilihat pada bab 7 hal 49-51.

Jika di zoom out, Kampong kami adalah kampong terkaya di Indonesia. Inilah kampong tambang yang menghasilkan timah dengan harga segenggam lebih mahal puluhan kali lipat disbanding segantang padi. Triliunan rupiah asset tertanam di sana, miliaran rupiah uang berputar sangat cepat seperti putaran mesin parut, dan miliaran dolar devisa mengalir deras seperti kawanan tikus terpanggil pemain seruling ajaib Der Ratenfanger van Hamel. 
Hanya beberapa jengkal di luar lingkungan tembok tersaji pemandangan kontras seperti langit dan bumi. Berlebihan jika disebut daerah kumuh tapi tak keliru jika diumpamakan pemakaman kota yang dilanda gerhana berkepanjangan sejak era pencerahan revolusi industry. Di sana di luar lingkar tembok gedong hidup komunitas melayu belitong yang jika belm mempunyai enam orang anak belum berhenti beranak pinak

\section{Analisis Unsur Ekstrinsik Pada Novel Laskar Pelangi Karya Andrea Hirata}

\section{A. BIOGRAFI PENGARANG}

Andrea Hirata Seman Said Harun lahir di Pulau Belitung 24 Oktober 1982, Andrea Hirata sendiri merupakan anak keempat dari pasangan Seman Said Harunayah dan NA Masturah. Ia dilahirkan di sebuah desa yang termasuk desa miskin dan letaknya yang cukup terpelosok di pulau Belitong. Tinggal di sebuah desa dengan segala keterbatasan memang cukup mempengaruhi pribadi Andrea sedari kecil. Ia mengaku lebih banyak mendapatkan motivasi dari keadaan di sekelilingnya yang banyak memperlihatkan keperihatinan. Andrea diambil dari nama seorang wanita yang nekat bunuh diri bila penyanyi pujaannya, yakni Elvis Presley tidak membalas suratnya," ungkap Andrea. Sedangkan Hirata sendiri diambil dari nama kampung dan bukanlah nama orang Jepang seperti anggapan orang sebelumnya. Sejak remaja itulah, pria asli Belitong ini mulai menyandang nama Andrea Hirata. Andrea tumbuh seperti halnya anakanak kampung lainnya. Dengan segala keterbatasan, Andrea tetap menjadi anak periang yang sesekali berubah menjadi pemikir saat menimba ilmu di sekolah. Selain itu, ia juga kerap memiliki impian dan mimpi-mimpi di masa depannya.

Seperti yang diceritakannya dalam novel Laskar Pelangi, Andrea kecil bersekolah di sebuah sekolah yang kondisi bangunannya sangat mengenaskan dan hampir rubuh. Sekolah yang bernama SD Muhamadiyah tersebut diakui Andrea cukuplah memperihatinkan. Namun karena ketiadaan biaya, ia terpaksa bersekolah di sekolah yang 
bentuknya lebih mirip sebagai kandang hewan ternak. Kendati harus menimba ilmu di bangunan yang tak nyaman, Andrea tetap memiliki motivasi yang cukup besar untuk belajar. Di sekolah itu pulalah, ia bertemu dengan sahabatsahabatnya yang dijuluki dengan sebutan Laskar Pelangi.

\section{B. LINGKUNGAN}

\section{MASYARAKAT}

\section{PENGARANG}

1. Latar Belakang Tempat

\section{Tinggal}

Lingkungan tempat tinggal pengarang mempengaruhi psikologi penulisan novel. Apalagi novel "Laskar Pelangi" merupakan adaptasi dari cerita nyata yang dialami oleh pengarang langsung. Letak tempat tinggal pengarang yang jauh berada di Desa Gantung, Kabupaten Gantung, Belitong Timur, Sumatera Selatan ternyata benarbenar dijadikannya latar tempat bagi penulisan novelnya.

\section{Latar Belakang Sosial dan} Budaya

Pada novel ini banyak sekali unsur-unsur sosial dan budaya masyarakat yang bertempat tinggal di Belitong. Adanya perbedaan status antara komunitas buruh tambang dan komunitas pengusaha yang dibatasi oleh tembok tinggi merupakan latar belakang sosial. Dimana interaksi antara kedua komunitas ini memang ada dan saling ketergantungan. Komunitas buruh tambang memerlukan uang untuk melanjutkan kehidupan, sedang komunitas pengusaha memerlukan tenaga para buruh tambang untuk menjalankan usaha mereka.

\section{Latar Belakang Religi} (agama)

Latar belakang religi atau agama si pengarang sangat terlihat seperti pantulan cermin dalam novel "Laskar Pelangi" ini. Nuansa keislamannya begitu kental. Dalam beberapa penggalan cerita, pengarang sering kali menyelipkan pelajaran-pelajaran mengenai keislaman.

\section{Latar Belakang Ekonomi} Sebagian masyarakat Belitong mengabdikan dirinya pada perusahaan-perusahaan timah. Digambarkan dalam novel bahwa Belitong adalah pulau yang kaya akan sumber daya alam. Namun tidak semua masyarakat Belitong bisa menikmati hasil bumi itu. PN 


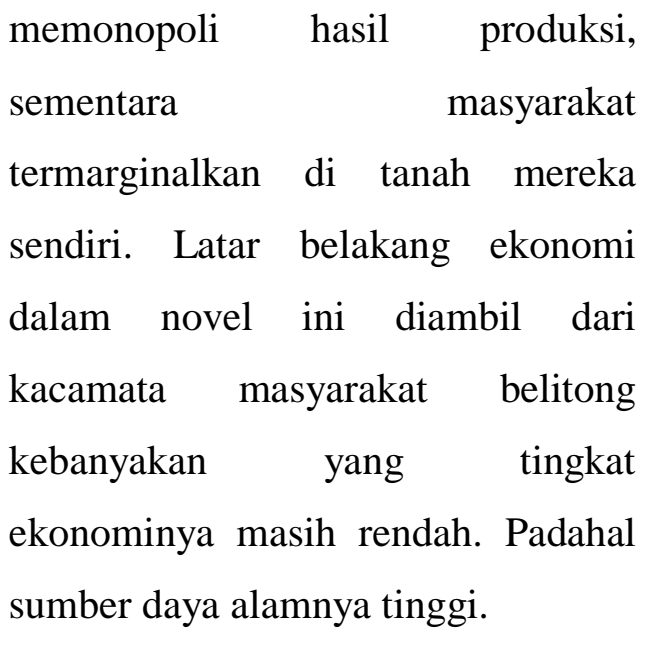

\section{SIMPULAN}

Berdasarkan analisis diatas, dapat disimpulkan bahwa analisis terhadap sebuah karya sastra dapat dilakukan dengan pendekatan unsur intrinsik dan ekstrinsik. Tema Penokohan, Alur, Latar, Sudut Pandang, Amanat, Gaya Bahasa sedangkan unsur ekstrinsik prosa terbagi atas empat bagian yaitu Biografi Pengarang, Psikologi Pengarang, Lingkungan Masyarakat Pengarang, Pemikiran Pengarang

\section{SARAN}

Menganalisis sebuah novel perlu diperhatikan teori-teori pendekatan yang mendukung. Penulis dalam makalah ini hanya menggunakan pendekatan unsur intrinsik dan ekstrinsik. Jadi, untuk peneliti selanjutnya diharapkan dapat menggunakan

pendekatan- pendekatan yang lain. Selain itu, makalah ini juga dapat digunakan sebagai referensi untuk peneliti lain.

\section{DAFTAR PUSTAKA}

A.Teeuw. 2015. Sastra dan Ilmu Sastra.Bandung :PT Dunia Pustaka Jaya

Depdiknas. 2012. Kamus Besar Bahasa Indonesia. Jakarta : Balai Pustaka

Editorial Padi. 2013. Kumpulan Super Lengkap Sastra Indonesia. Jakarta:Padi

Endraswara, Suwardi. 2015. Sejarah Sastra Jawa.Yogyakarta: Penerbit Ombak

Hirata, Andrea. 2008. Laskar Pelangi.

Yogyakarta:Bentang

Ismawati, Esti. Kritik Sastra. Yogyakarta : Penerbit Ombak

Mursini. 2010. Bimbingan Apresiasi Sastra Anak-anak. Medan: USU Press

Sehandi ,Yohanes. 2014. Mengenal 25 Teori Sastra. Yogyakarta: Penerbit Ombak

Suaka, Nyoman. 2014. Analisi Sastra Teori dan Aplikasi. Yogyakarta: Penerbit Ombak

Wellek Rene dan Austin Warren. 1989. Teori Kesusastraan. Jakarta : PT. Gramedia

Yodiono. 2002. Pengantar Sejarah Sastra Indonesia . Jarkarta : PT

Grasindo 